\title{
The Prospects of Wooden Building Construction in Malaysia: Current State of Affairs
}

\author{
Hazirah Ab Latib, ${ }^{\mathrm{a}, *}$ Lum Wai Cheong, ${ }^{\mathrm{b}}$ Rasmina Halis, ${ }^{\mathrm{a}}$ Mohamad Roslan Mohamad \\ Kasim, ${ }^{\mathrm{a}}$ Lee Yan $\mathrm{Yi}^{\mathrm{a}}{ }^{\mathrm{a}}$ Jegatheswaran Ratnasingam, ${ }^{\mathrm{a}, *}$ and Florin Ioras ${ }^{\mathrm{c}}$
}

\begin{abstract}
The objective of this study was to evaluate the extent to which the practicing architects in Malaysia were familiar with timber products as a construction material. The materials consumption data was extracted from the Construction Industry Development Board (CIDB) database and was used to conduct a survey among 189 respondent architects. The results indicated that the architects were familiar with common timber products such as plywood, fiberboard, particleboard, and laminated veneer lumber. Correlation analysis of awareness and knowledge against the rate of utilization of these timber products was significant. Furthermore, the most important deterrent factors for the use of timber products in building construction in Malaysia were the high cost, poor durability, restrictive building codes and by-laws, as well as the low fire resistance. More aggressive promotion of timber products as a potential construction material is advisable to be undertaken when the goal is to boost the material's use in the construction industry. Policy makers may also consider providing financial incentives to increase timber products utilization in building construction in Malaysia.
\end{abstract}

Keywords: Wood products; Construction; Architects; Cost; Durability

Contact information: a: Faculty of Forestry, Universiti Putra Malaysia, 43400 UPM, Serdang, Selangor, Malaysia; b: Architects Association of Malaysia, 99L Jalan Tandok, Bangsar, 59100 Kuala Lumpur, Malaysia; c: Centre for Sustainability, Buckinghamshire New University, Queen Alexandra Road, High Wycombe, HP11 2JZ Bucks, England;

*Corresponding authors: hazirahablatib@yahoo.com; jegaratnasingam@yahoo.com

\section{INTRODUCTION}

As a fast developing country, Malaysia is committed to creating an economy based on the Sustainable Development Goals (SDG). In this context, green building initiatives have been receiving increased attention from government agencies, private organizations, and the public at large for almost a decade now. The launch of the National Green Technology Policy (NGTP) in 2009 clearly highlighted the government's focus on creating a green and sustainable economy, with a special focus on the production of renewable energy (RE) and the intensification in the practice of energy efficiency (EE) throughout the country. One of the areas that was given priority in the NGTP was the increased construction of green and energy efficient buildings, especially through the use of wood and wood products, which was to be rated under the Green Building Index (GBI). Table 1 shows the development of the various building and energy related policies and initiatives championed by the government in consultation with the various stakeholders since the 1970s. 
Table 1. Building and Energy Related Policies and Initiatives by Government

\begin{tabular}{|c|c|c|}
\hline Year & Policies/Programmes & Agency \\
\hline $\begin{array}{l}1970 \mathrm{~s} \\
\text { to } \\
2000 \mathrm{~s}\end{array}$ & $\begin{array}{ll}\text { - } & \text { National Energy Policy (1979) } \\
\text { - } & \text { National Depletion Policy (1981) } \\
\text { - } & \text { Four Fuel Diversification Policy (1981) } \\
\text { - } & \text { The Electricity Supply Act } 1990 \text { and the Electricity Supply Act } \\
\text { - } & \text { (Amended) } 2001 \\
\text { - National Policy on the Environment (2002) }\end{array}$ & \\
\hline $\begin{array}{c}2001 \\
\text { to } \\
2008\end{array}$ & 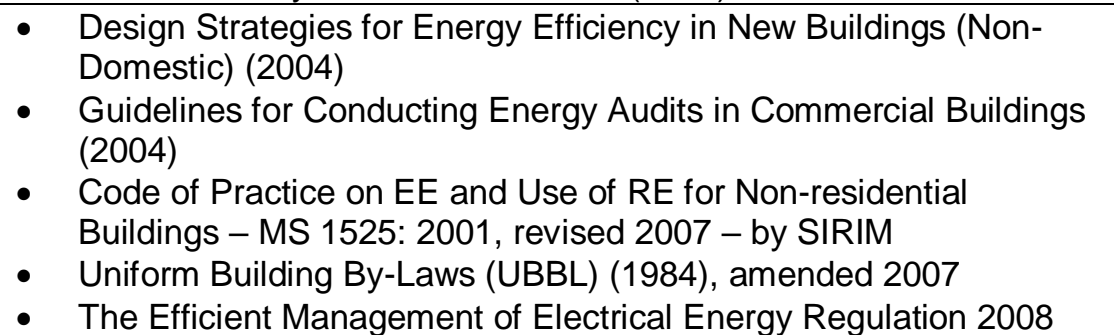 & \\
\hline & $\begin{array}{l}\text { - National Green Technology Policy } \\
\circ \quad \text { National Energy Centre (PTM) restructuring to Malaysian } \\
\text { Green Technology Corporation (MGTC) } \\
\text { Green Technology Financing Scheme (GTFS) (2010-2015) } \\
\quad \text { Approved GT Value for Financing (RM): } \\
\quad \begin{array}{l}1,118,895,405.00 \\
\text { Balance of GT Value for Financing (RM): } \\
2,381,104,505.00\end{array} \\
\circ \quad \text { Green Township in Putrajaya and Cyberjaya } \\
\circ \quad \text { International Greentech and Eco Products Exhibition and } \\
\text { Conference Malaysia (IGEM) }\end{array}$ & $\begin{array}{l}\text { Ministry of } \\
\text { Energy, } \\
\text { Science, } \\
\text { Technology, } \\
\text { Environment } \\
\text { and Climate } \\
\text { Change } \\
\text { (MEGTW) }\end{array}$ \\
\hline 2009 & $\begin{array}{l}\text { - National Policy on Climate Change } \\
\text { - Green Building Index (GBI) } \\
\circ \quad \text { Developed by Malaysian Institute of Architects (PAM) and } \\
\text { the Association of Consulting Engineers Malaysia (ACEM) } \\
\text { supported by Malaysia Green Building Confederation } \\
\text { (MGBC). Separates Between Residential \& Non-residential } \\
\text { - the non-residential rating tools are customized by nature } \\
\text { of whether they are commercial, industrial or institutional - } \\
\text { including the Industrial Rating Tool } \\
5 \text { criteria measuring energy efficiency (EE) - indoor } \\
\text { environment quality, sustainable site and management, } \\
\text { materials and resources, water efficiency, and innovation }\end{array}$ & $\begin{array}{l}\text { Ministry of } \\
\text { Natural } \\
\text { Resources } \\
\text { and } \\
\text { Environment } \\
\text { (MNRE) }\end{array}$ \\
\hline 2010 & 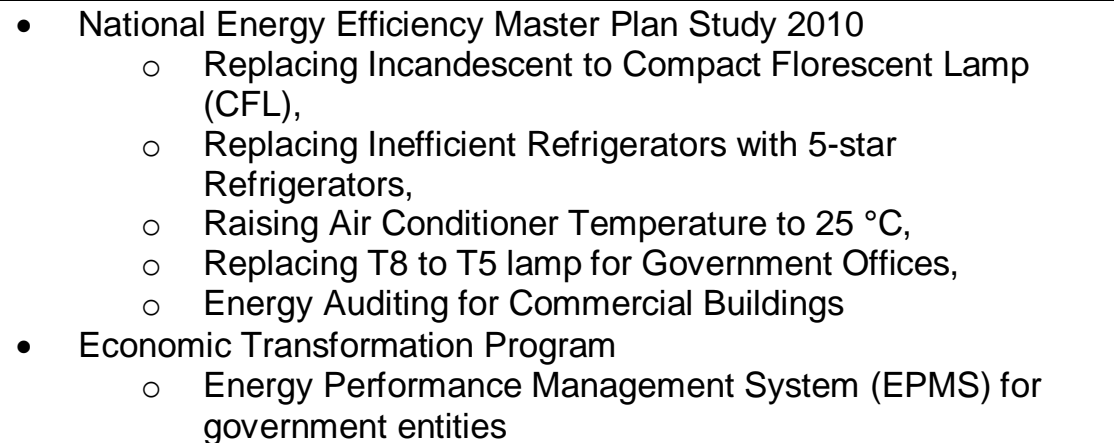 & MEGTW \\
\hline
\end{tabular}




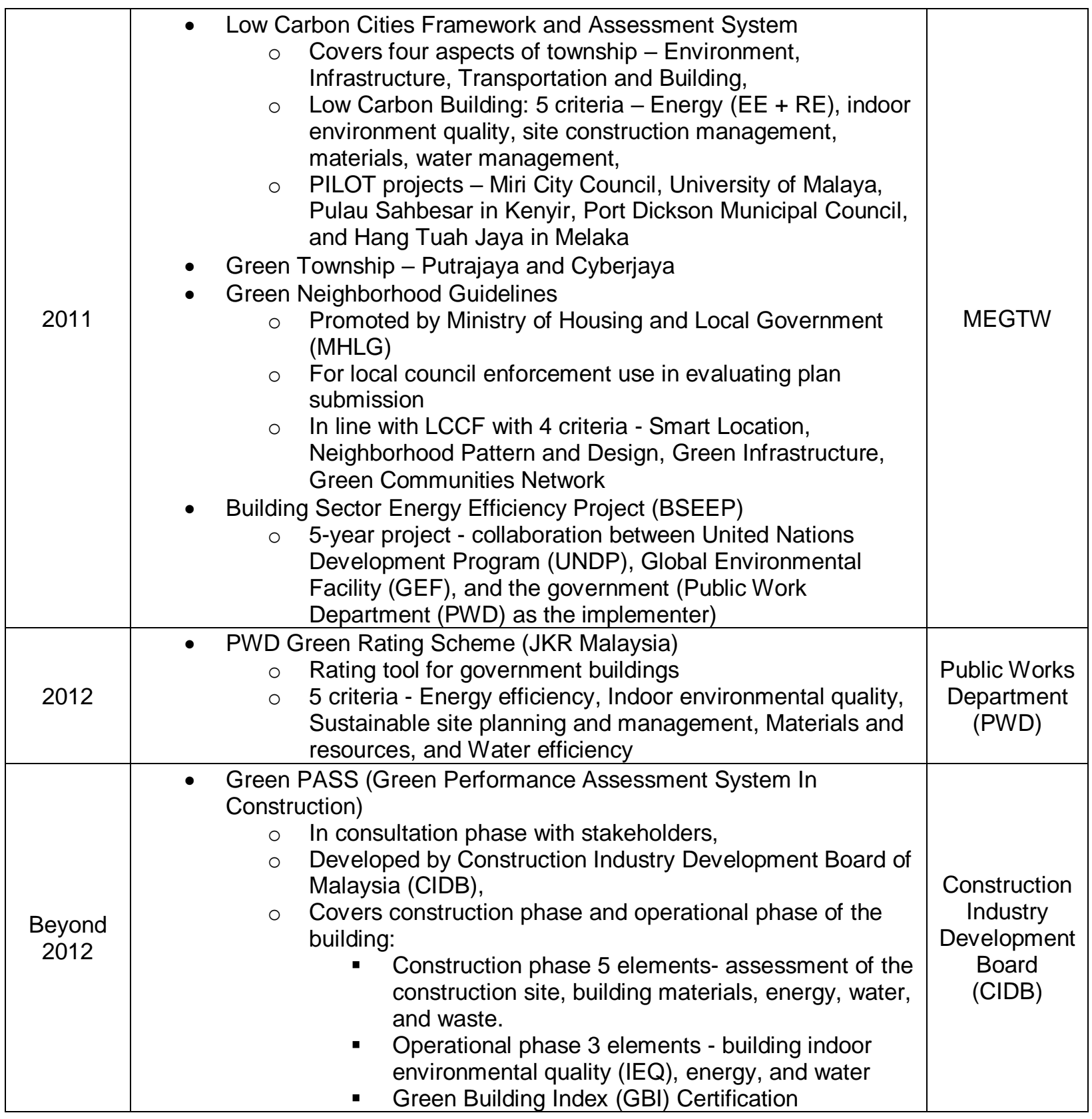

Therefore, it is apparent that Malaysia is geared towards embracing the concept of green building construction in an extensive manner, within a construction industry that is predominated by non-environmental friendly material use, as well as less energy efficient buildings (CIDB 2018).

\section{Overview of the Malaysian Construction Industry}

In 2018, the construction sector in Malaysia was valued at RM 141.8 billion, with the residential housing sector contributing almost $43 \%$ to this total (Bank Negara Malaysia 2019). Despite being a large producer and exporter of wood products in the world, the use of wood materials and wood products in the domestic construction sector is relatively small 
(CIDB 2018). Although the wooden roof trusses has been extensively used in Malaysia previously, since 2003 the aluminum roof trusses has been gaining prominence and successfully replaced the traditional wooden roof trusses for almost all applications (Ratnasingam et al. 2018).

Although wood is one of the oldest materials that had been used for construction, its lesser utilization compared to all other building materials is broadly acknowledged by architects and contractors in Malaysia (Ratnasingam et al. 2018). Despite such a market scenario, Malaysian exporters of wooden construction components and parts have been doing extremely well in the global market and have broken new deals in many countries, as wood items, by and large, have gained wide application and inclusion, in term of its functionality and aesthetics (Bysheim and Nyrud 2008). In 2018, the export value of wooden construction components reached almost USD 250 million (MTIB 2019).

Similar to other countries, in Malaysia the building development and construction involves three major parties: the owner, architect/contractor, and the local building council/authority. The final design, planning, and construction of the building are often a compromise between the owner and the architect/contractor to ensure compliance with local building by-laws as well as the related economic and environmental factors (Chua and $\mathrm{Oh}$ 2011). In this context, studies on the preferential use of wood and wood products in the Malaysian construction sector are limited (Ratnasingam et al. 2018; Zakiah et al. 2018), and therefore the topic warrants further research into the main challenges and drivers that limit wood and wood products utilizations in building construction in the Malaysian context.

In contrast, studies on the use of wood and wood products in building construction in the developed world are quite extensive. In a survey regarding consumers' attitudes towards wood as a construction material, the most decisive criteria were appearance, comfort, and health issues related to allergy prevention and air quality (Gold and Rubik 2009). Other factors, such as quality, structural and environmental performance, fire resistance, maintenance, and costs were also noted as important criteria (Mahmoudkelaye et al. 2018). The study by Bysheim and Nyrud (2008) raised doubts about the use of wood and wood products for building construction, especially when it comes to its fire performance, maintenance cost, and initial construction cost.

Previous studies in many other countries have shown that consumers, architects, and contractors have different perceptions of wood and wood products as a construction material, and the decision to specify and use it for construction purposes is determined by several opposing factors (Roos et al. 2010). In the context of Malaysia, this is particularly true because of the socio-economic background of the society and the low level of awareness of the prevailing green economy (including green buildings) and its true potential. From the government's perspective, the success of the green technology agenda in the country is dependent on the uptake of the idea by the society at large, although facilitating policy framework and regulations are already in place (Zakiah et al. 2018). Against this background, the objectives of this study were to: (1) determine the trends in materials used, (2) identify the types of buildings with the highest potential for wood products use, and (3) propose the necessary facilitating framework to encourage higher use of wood and wood products in Malaysian construction sector. 


\section{EXPERIMENTAL}

\section{Materials}

To evaluate the trends in the use of different construction materials from 2013 to 2017, a thorough review of the materials database at the CIDB and the PWD were initially undertaken. The average annual amount of the different types of construction materials consumed were compiled, analyzed, and presented in Fig. 1.

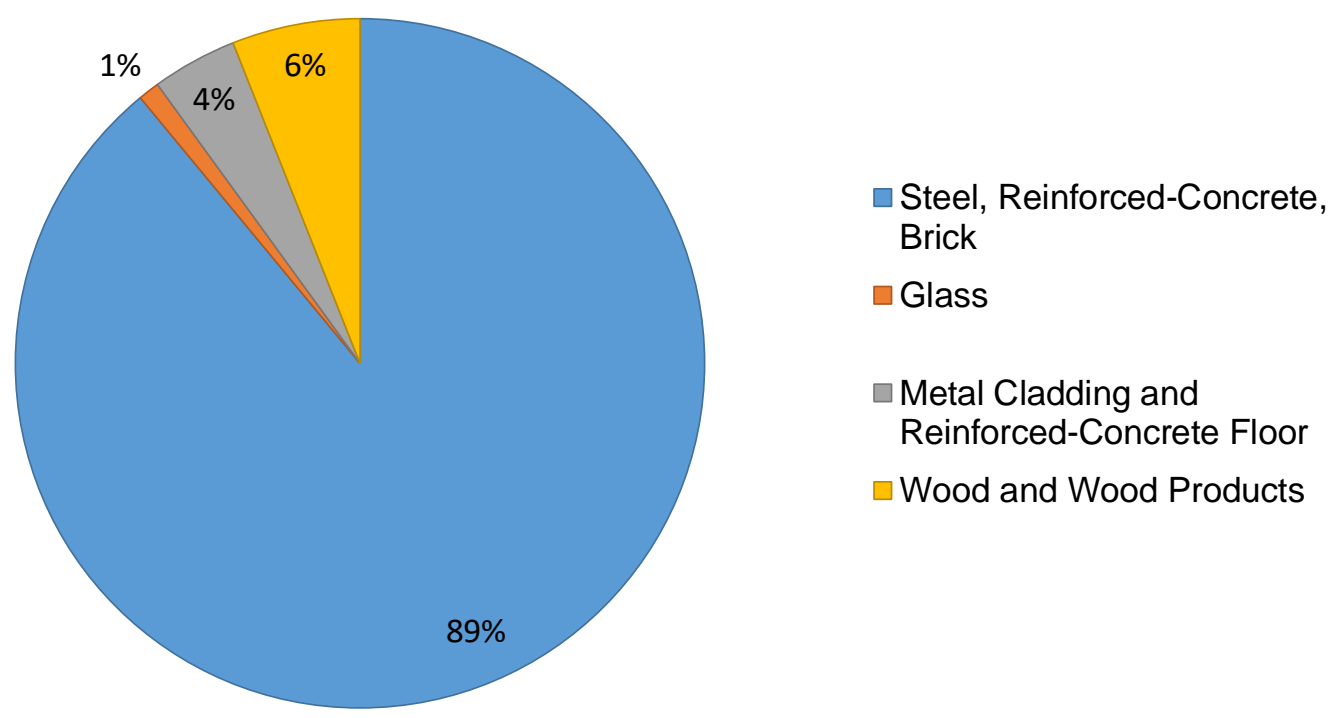

Fig. 1. Types of construction materials used (2013 to 2017)

Based on the data shown in Fig. 1, on the different construction materials used from 2013 to 2017, a questionnaire-based survey was undertaken to obtain feedback from practicing architects throughout Malaysia, to gather information on the trends observed, and also to further collect information to fulfill the objectives of this study.

The design of the questionnaire was based on the previous study by Ratnasingam et al. (2018) and also consulting with several practicing architects and academics working on wood as structural materials and wooden structures. A pre-test of the questionnaire was initially completed with the assistance of 25 architects in the Klang Valley, and based on their feedback and comments, the questionnaire was improved for clarity and ease of implementation. The questionnaire was bilingual, both in the Malay and English languages.

The questionnaire-based survey was then implemented with the assistance of the Architects Association of Malaysia (AAM), and a total of 300 potential respondent architects were approached, with a response rate of $63 \%$, or 189 successful responses. The 300 potential respondent architects were randomly selected, on the basis of their previous and current experiences in wood-related constructions from the AAM database.

The first part of the questionnaire was aimed at compiling information on the background of the respondent architect and about his/her practice in the construction industry. The second part of the questionnaire, had a total of 10 questions, which were aimed at evaluating the level of awareness and knowledge the respondent architects had 
about different wood and wood products available for use in the construction industry in Malaysia. The responses to these questions were based on the 5-point Likert scale, from 1 (being the lowest) to 5 (being the highest).

The third part of the questionnaire focused on the respondent architects' experience in specifying various types of wood and wood products for either structural or nonstructural applications. A total of 10 types of wood and wood products were listed, and the respondent architects had to choose whether the material was specified for either structural or non-structural applications.

The fourth part of the questionnaire required the respondent architects to rank the various factors listed by their importance, which had influenced their decision to specify and use wood and wood products in their building projects. A total of 10 factors were listed, which included high cost, inconsistent availability, lack of durability, poor fire resistance, restrictive building codes and by-laws, inconsistent material quality, insufficient awareness of the material, poor implementation of the specifying and verifying services by the regulatory agency, lack of market demand, and preference for only selective wood species.

The fifth part of the questionnaire required the respondent architects to make 10 suggestions that would help to boost the use of wood and wood products in the construction industry, in line with the National Green Technology Plan (NGTP).

\section{Methods}

Data analysis

The data obtained from the survey of the architects were analyzed using the Statistical Package for Social Sciences (SPSS) software version 16.0 (IBM, version 25, New York, USA). The data obtained were compiled, tabulated, and subjected to three types of statistical tests, i.e., descriptive analysis, chi-square test, and the rank-correlation analysis. The descriptive analysis was used to describe the basic features of the data obtained from the survey, while the Chi-Square test was performed to determine the relationship between categorical variables. The Spearman's rank-correlation analysis measured the ordinal relationship between rankings of different ordinal variables, and the rank-correlation coefficient provides the significance between the variables. The level of significance for all the tests conducted in this study was maintained at $\mathrm{p}<0.05$ (Box 1987; Pallant 2010).

\section{RESULTS}

The results of the survey suggested that the architects had a good level of awareness and knowledge of the common types of timber products in the market, especially plywood, fiberboard, particleboard, laminated veneer lumber (LVL), cross-laminated timber (CLT), and oriented strand board (OSB) (Table 2.). However, the other timber products appeared to be at a lower level of awareness and knowledge $(<50 \%)$ among the respondent architects. It was also noted that the architects were more familiar with some of the timber products listed, as they have either been covered in their professional education curriculum (Ratnasingam et al. 2018), or these products have been promoted by suppliers and are included in the CIDB recommended materials registration list (Mohamed et al. 2015). As shown in Table 2, the Pearson's chi-square tests for plywood, fiberboard, particleboard, 
and LVL showed a significant relationship between the level of awareness and knowledge against their use by architects, while the other timber products did not show any significant relationship.

Studies by Ratnasingam and Chung (2016) and Murad et al. (2017) have shown that timber products familiarity increase among specifiers and designers when the products are amply available and produced locally in the market. Similar observations have also been made by O'Connor et al. (2004), Bysheim and Nyrud (2008), and Li and Xie (2013) on studies in US, Scandinavia, and Taiwan, respectively. In this case, being a large producer and exporter of plywood, fiberboard, and particleboard in the Association of South East Asian Nations (ASEAN) region, it is no surprise that the awareness of these products among building professionals is good. In fact, plywood is reported to be the most important wood product used in the Malaysian construction sector, especially for formwork, construction moulds, and other structural applications (Ratnasingam et al. 2018).

Table 2. Level of Awareness and Knowledge of Architects against Timber Products

\begin{tabular}{|c|c|c|c|c|}
\hline \multirow{2}{*}{ Timber Products } & \multirow{2}{*}{$\begin{array}{c}\text { Awareness } \\
(\%)\end{array}$} & $\begin{array}{c}\text { Knowledge } \\
(\%)\end{array}$ & \multicolumn{2}{|c|}{$\begin{array}{c}\text { Relationship to Utilization in } \\
\text { Buildings }\end{array}$} \\
\cline { 4 - 5 } & & & $\begin{array}{c}\text { Pearson's Chi- } \\
\text { Square Value }\end{array}$ & P-Value \\
\hline Plywood & 100 & 100 & 4.59 & 0.041 \\
\hline Fiberboard & 100 & 90 & 4.51 & 0.038 \\
\hline Particleboard & 100 & 90 & 4.51 & 0.038 \\
\hline OSB & 80 & 70 & 4.56 & 0.066 \\
\hline Glued laminated timber (GLT) & 100 & 80 & 6.18 & 0.056 \\
\hline LVL & 100 & 80 & 7.04 & 0.047 \\
\hline CLT & 45 & 30 & 9.28 & 0.176 \\
\hline Parallel strand lumber (PSL) & 40 & 20 & 11.34 & 0.213 \\
\hline $\begin{array}{c}\text { Laminated strand lumber } \\
\text { (LSL) }\end{array}$ & 30 & 10 & 11.81 & 0.361 \\
\hline $\begin{array}{c}\text { Transparent wood } \\
\text { composites (TWC) }\end{array}$ & 30 & 10 & 11.93 & 0.377 \\
\hline
\end{tabular}

In contrast, the newer timber products in market, such as CLT, LSL, etc., that are not presently, commercially, and locally produced, have a much lower level of awareness among the architects. Therefore, the findings of the study emphasize the fact that for timber products to be widely specified and used for building construction, a sizeable domestic production volume is necessary to ensure a consistent exposure in the domestic construction materials marketplace (Ratnasingam et al. 2018). A similar observation was also made by Zakiah et al. (2018), who suggested that the lack of supply of heavy hardwoods in the market, including species such as Kempas (Koompassia malaccensis), Tualang (Koompassia excelsa), Selangan Batu (Shorea laevifolia), Balau (Shorea laevis), Resak (Vatica rassak), and Merbau (Intsia palembanica), imposed constraints on specifying established construction-grade timber for applications in buildings. Being established construction timber species, its limited supply presently in the marketplace not only makes its unaffordable to most consumers, but in essence also reduces the familiarity of timber products among the Malaysian society at large. Perhaps this explains the increasing trend of using over-lays and printed non-timber products that are camouflaged with a wood appearance in many construction projects throughout the country (Nathan 
2018). In this context, a more aggressive awareness and knowledge-imparting sessions about the advantages of using timber products should be pursued by all relevant agencies to increase the market share of timber products in the domestic construction market (Zakiah et al. 2018).

Figure 2 shows the utilization of specific timber products for either structural or non-structural applications, or both. As noted earlier, plywood is the most widely used timber products for both structural and non-structural applications in the construction industry in Malaysia. Other timber products used in structural applications include LVL, GLT, and OSB. In contrast, fiberboard and particleboard are solely used for non-structural application due to their lower strength, durability, and moisture resistance (Kodur and Harmathy 2016). These products often find application in furniture products and other indoor applications.

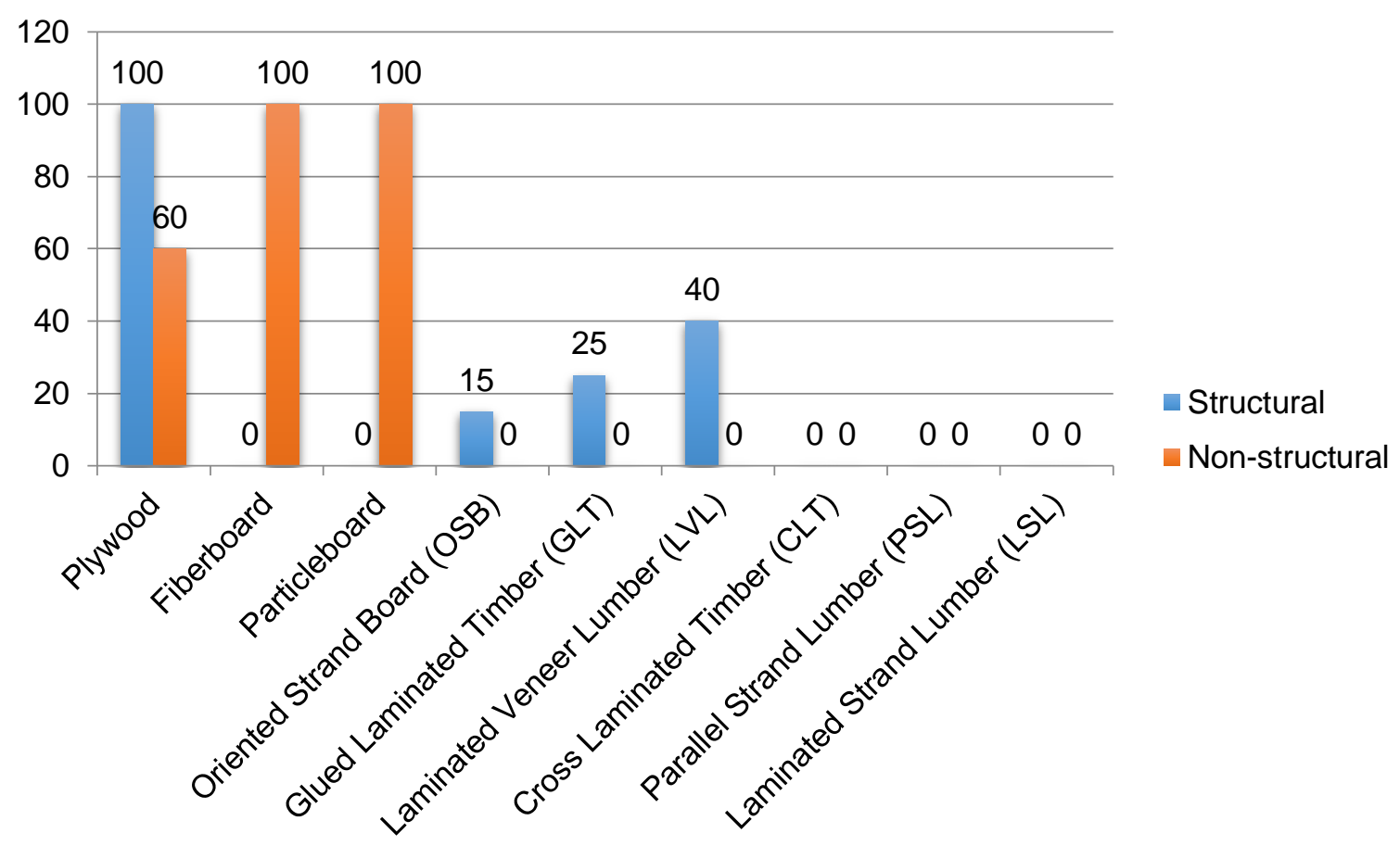

Fig. 2. Utilization of specific timber products

It must be stated that the architects' level of awareness and knowledge of the specific timber products also affects their potential use (Roos et al. 2010). In this context, there was a strong correlation between the level of awareness and knowledge of timber products among architects and their specific use in buildings (Table 3) in Malaysia, similar to architects in other countries as reported by Li and Xie (2013), Hemström et al. (2011), Bysheim and Nyrud (2008), and O'Connor et al. (2004). In a study by Collins et al. (2016) it was reported that owners of bungalows and other types of land properties showed a higher preference for using timber products for both structural and non-structural applications, compared to owners of other types of buildings in the ASEAN region. The study further implied that when the country was a large exporter of timber products, there appeared to be a tendency for a lower consumption of timber products for construction 
purposes in the domestic market due to limited supply, and the correspondingly high price of the material.

Table 3. Correlation Between the Level of Awareness and Knowledge

\begin{tabular}{|c|c|}
\hline Timber Products & Spearman's Rank Correlation \\
\hline Plywood & 0.98 \\
\hline Fiberboard & 0.93 \\
\hline Particleboard & 0.89 \\
\hline OSB & 0.78 \\
\hline GLT & 0.81 \\
\hline LVL & 0.83 \\
\hline CLT & 0.21 \\
\hline PSL & 0.27 \\
\hline LSL & 0.31 \\
\hline Transparent wood composites & 0.18 \\
\hline (TWC) &
\end{tabular}

Note: P-value taken at 0.05

Table 4 shows the degree of importance of the various factors in determining the decision to specify and utilize timber products for a particular building project. The frequency of responses clearly shows that the four main factors affecting the use of timber products for construction purposes are cost, durability, building codes and by-laws, and fire-resistance. A similar finding was also reported by Ratnasingam et al. (2018), which further implied that a review of the existing building codes and by-laws in the country that does not encourage the use of timber products warrants immediate action. Being a net exporter of wood products, there is a general perception in the country that the wood products available for domestic used is of lower quality and is not very durable. This perception is strengthened by the fact that the Malayan Grading Rule (MGR), which is the mark of quality for wood products exported from Malaysia, is not applied to wood products used in the domestic market (Ratnasingam et al. 2018). Another point of concern is the fact that the building by-laws including the fire rating of buildings in the country have not been revised since the British colonial days, which is seen to be outdated by many architects and contractors in the country (Ratnasingam et al. 2018).

According to Zakiah et al. (2018), there appears to be a mismatch between the quality and availability of certain timber products that are subjected to stringent quality control standards and are often exported, while in the domestic market, timber products are often purchased on a willing-seller, willing-buyer basis, and the enforcement of quality standards is not mandatory. Inevitably, the bad reputation for timber products in the domestic market appears to come from a few isolated cases of product failure and poor performances, which has adversely affected the preferences for specifying and using timber products for building construction purposes (CIDB 2017). Although the Malaysian Timber Industry Board (MTIB) offers a verification service for timber products, the uptake for such services in the domestic market appears limited, as there is a general lack of concerted effort to reverse the negative perception against timber products among consumers in the domestic market (CIDB 2017). 
Table 4. Degree of Importance of the Various Factors

\begin{tabular}{|c|c|c|c|}
\hline Factors & Ranking & $\begin{array}{c}\text { Frequency of } \\
\text { Responses }(\%)\end{array}$ & $\begin{array}{c}\text { Rank Correlation } \\
\text { Coefficient }\end{array}$ \\
\hline Cost & 1 & 93 & 0.91 \\
\hline Availability & 5 & 71 & 0.43 \\
\hline Durability & 2 & 87 & 0.89 \\
\hline Fire resistance & 4 & 81 & 0.72 \\
\hline Building codes and by-laws & 3 & 84 & 0.81 \\
\hline Material quality & 7 & 60 & 0.19 \\
\hline Material awareness & 9 & 52 & 0.07 \\
\hline $\begin{array}{c}\text { Specifying and verifying services } \\
\text { by the regulatory agency }\end{array}$ & 10 & 44 & -0.26 \\
\hline Market demand & 6 & 65 & 0.39 \\
\hline $\begin{array}{c}\text { Preference for selective wood } \\
\text { species }\end{array}$ & 8 & 58 & -0.03 \\
\hline
\end{tabular}

According to the CIDB (2017), wooden construction is also preferred in the Western countries due to the high energy cost attributed to the need for heating and cooling throughout the year. Unfortunately, the low energy cost in Malaysia does not augur well to this cause, because almost all buildings are cooled in the tropical heat through airconditioning rather than using timber products for its good heat insulating property. Ironically, this requirement is also part of the NGTP, and should therefore, be strictly adhered to ensure and boost the use of timber products in the construction sector in the country.

In this context, building professionals and building owners who resort to the use of timber products beyond a certain volume threshold should be financially rewarded through incentives, which would encourage others to follow suit, in line with the government's NGTP.

\section{Recommendations to Boost Timber Products Use in Building Construction}

Based on the architects' responses of the survey, the three most prominent recommendations that have been put forward to boost the use of timber products in building construction in Malaysia are:

(1) For all public buildings, at least $30 \%$ of all materials used must be wood-based, while for private buildings at least $15 \%$ of the material used should be wood-based materials to obtain the approval of the local councils and building authorities;

(2) Buildings that are designed to use timber products for structural purposes should be rewarded from special incentives of a scheme set up by the government; and

(3) Timber products of verified quality must be available in the domestic market in sufficient supply at reasonable prices, through the imposition of a quota for domestic supply.

Other suggested recommendations included a complete ban on the export of timber products based on the highly desirable wood species used for construction purposes; the increased awareness on the use of timber products for architects, building authorities, local councils, and consumers prompting the research and development (R\&D) activities on use of timber products for structural purposes, and also to replace the traditional construction 
materials and the erection of model wooden structures at specific locations throughout the country to exemplify the use of timber products and showcase its performance.

In a study on wooden buildings in Australia, it was revealed that increasing the use of timber products is a long-term effort, especially to convince consumers in the material's properties and performance before they appreciate the use of timber products in buildings (Lendlease 2016). In this context, building professionals (including architects, specifiers, and contractors) as well as the building authorities and local councils have to provide a positive outlook for the material based on its performance and reliability data. In fact, the provision of financial incentives for the use of timber products in building constructions could also result in positive outcomes.

In this context, this study has far reaching implications on the use of timber products in building constructions of Malaysia, and the aggressive promotion of timber products as a potential construction material not only for consumers but also to architects and local buildings authorities should be undertaken. Providing financial incentives to boost timber products use in buildings should also be a point for consideration by policymakers in Malaysia.

\section{CONCLUSIONS}

1. This research emphasized the fact that timber products are currently not the preferred choice of material for building construction in Malaysia. Steel-reinforced concretebrick construction remains as the predominant construction material-mix used in the country.

2. This study reaffirmed the fact that plywood is the most common timber product used within the construction sector, followed by fiberboard, particleboard, and LVL.

3. The results also showed that the deterrents to use timber products in building constructions are the high cost, perceived poor durability, restrictive building codes and by-laws, and poor fire resistance.

4. To encourage wider utilization of timber products in building construction in Malaysia, aggressive efforts to improve the awareness and knowledge of the material among the general public, as well as the practicing architects, other building professionals, and local building councils should be undertaken.

5. The provision of financial incentives to boost the use of timber products in building constructions should also be considered by policymakers.

\section{ACKNOWLEDGEMENTS}

The assistance of the Architects' Association of Malaysia (AAM) in implementing the survey is appreciated and the financial support from Universiti Putra Malaysia under the PUTRA-IPS Grant (No. 9610200) is acknowledged. 


\section{REFERENCES CITED}

Bank Negara Malaysia (2019). Report on the Performance of the Construction and Housing Sector in Malaysia, Bank Negara Malaysia, Kuala Lumpur, Malaysia.

Box, J. F. (1987). “Guinness, gosset, fisher, and small samples," Statistical Science 2(1), 45-52. DOI: $10.1214 / \mathrm{ss} / 1177013437$

Bysheim, K., and Nyrud, A. Q. (2008). “Architect's perceptions of structural timber in urban construction," in: Conference Cost E53, Delft, Netherlands, pp. 75-86.

Chua, S. C., and Oh, T. H. (2011). "Green progress and prospect in Malaysia," Renewable and Sustainable Energy Reviews 15(6), 2850-2861. DOI:

10.1016/j.rser.2011.03.008

CIDB (2017). Annual Review of Construction Industry in Malaysia, Construction Industry Development Board, Kuala Lumpur, Malaysia.

CIDB (2018). Annual Review of Construction Industry in Malaysia, Construction Industry Development Board, Kuala Lumpur, Malaysia.

Collins, M., Nathan, P. S., and Omar, T. K. (2016). "Wood products as a material to value-add in landed properties in Malaysia," in: CIDB Study 17PS-T. Construction Industry Development Board, Kuala Lumpur, Malaysia. pp. 63.

Gold, S., and Rubik, F. (2009). "Consumer attitudes towards timber as a construction material and towards timber frame houses: Selected findings of a representative survey among the German population," Journal of Cleaner Production 17(2), 303309. DOI: $10.1016 /$ j.jclepro.2008.07.001

Hemström, K., Mahapatra, K., and Gustavsson, L. (2011). "Perceptions, attitudes and interest of Swedish architects towards the use of wood frames in multi-storey buildings," Resources, Conservation and Recycling 55(11), 1013-1021. DOI: 10.1016/j.resconrec.2011.05.012

Kodur, V. K. R., and Harmathy, T. Z. (2016). "Properties of building materials," in: SFPE Handbook of Fire Protection Engineering, Springer, New York, NY, USA, pp. 277-324.

Lendlease (2016). Annual Report of the Construction Sector in Australia, Lendlease PLC, Melbourne, Australia.

Li, S. H., and Xie, H. (2013). "Building professionals' attitudes towards the use of wood in building design and construction in Taiwan," European Journal of Wood and Wood Products 71(4), 497-505. DOI: 10.1007/s00107-013-0688-1

Mahmoudkelaye, S., Azari, K. T., Pourvaziri, M., and Asadian, E. (2018). "Sustainable material selection for building enclosure through ANP method," Case Studies in Construction Materials 9, e00200. DOI: 10.1016/j.cscm.2018.e00200

Mohamed, M., Amini, M. H. M., Sulaiman, M. A., Bakar, M. B. A., Masri, M. N., Abdullah, N. H., Auli, N., Razab, M. K. A. A., and Rizman, Z. I. (2015). "CFD simulation using wood (Cengal and Meranti) to improve cooling effect for Malaysia green building," Journal of Engineering and Applied Sciences 10(20), 9462-9467.

MTIB (2019). Annual Report, Malaysian Timber Industry Board, Kuala Lumpur, Malaysia.

Murad, A. J., Hishamudin, M. K., and Tarmizi, W. (2017). Familiarity of Building Professionals Towards Timber Products in Asia (ADB Report No. 6.), Asian Development Bank Publications, Manila, Philippines. 
Nathan, P. S. (2018). "Use of overlay and surfacing material to value-add non-timber products," New Asian Woodworker 7(special issue), 16-19.

O'Connor, J., Kozak, R., Gaston, C., and Fell, D. (2004). "Wood use in nonresidential buildings: Opportunities and barriers," Forest Products Journal 54(3), 19-28.

Pallant, J. (2010). SPSS Survival Manual: A Step by Step Guide to Data Analysis Using SPSS, Open University Press, McGraw-Hill Education, Maidenhead, Berkshire, England.

Ratnasingam, J., Ab Latib, H. A., Ng, W. C., Cellathurai, M., Chin, K. A., Senin, A. L., and Lim, C. L. (2018). "Preference of using wood and wood products in the construction industry in peninsular Malaysia," BioResources 13(3), 5289-5302. DOI: 10.15376/biores. 13.3.5289-5302

Ratnasingam, J., and Chung, T. M. (2016). "Wood use in building construction: The Malaysian dimension," Asian Woodworker 14(3), 18-23.

Roos, A., Woxblom, L., McCluskey, D., Woxblom, A., and Mccluskey, L. (2010). "The influence of architects and structural engineers on timber in construction: Perceptions and roles," Silva Fennica 44(5), 871-884. DOI: 10.14214/sf.126

Zakiah, A., Marina, Y., Halilah, H., and Che Maznah, M. I. (2018). Study on the Use of Timber and Timber Products in the Malaysian Construction Industry (MTIB-UiTM Consultancy Report), Malaysian Timber Industry Board, Kuala Lumpur, Malaysia.

Article submitted: August 18, 2019; Peer review completed: October 19, 2019; Revised version received: October 23, 2019; Accepted: October 24, 2019; Published: October 28, 2019.

DOI: $10.15376 /$ biores.14.4.9840-9852 